Srećko Milačić ${ }^{1}$

University of Pristina, Faculty of Economics

Zoran Simonović ${ }^{2}$

Institute for Agricultural Economics, Belgrade

Aleksandar Kostić ${ }^{3}$

University of Pristina, Faculty of Economics
ORIGINAL SCIENTIFIC ARTICLE

DOI: $10.5937 /$ ekonomika2004013M

Received: May, 17. 2020.

Accepted: Jun, 18. 2020.

\title{
EUROPEAN MONETARY UNION AS A STABILIZING FACTOR IN THE CIRCUMSTANCES OF ECONOMIC CRISIS
}

\begin{abstract}
The authors examine the problems the European Monetary Union in the circumstances of the global economic crisis. They especially elaborated the battle for the financial stability of the European Monetary Union. The authors problematize the interaction of the European Central Bank and national central banks, emphasizing the deficiencies in the coordination of fiscal and monetary policy. They investigated the reasons that require a cautious strategy when it comes to the admission of new member states into the European Monetary Union and in that sense the conditions for nominal and real convergence. The authors consider the management of the economic crisis and the introduction of new institutions with the task to stabilize the situation in the monetary field. They explored the problems of helping countries like Greece from the point of view of the developed countries relationship. The authors especially paid attention to the level of transparency in relation to their citizens when making decisions on certain aid giving issues. They have proposed solutions for getting out of the vicious circle and the need to redesign the European Monetary Union and in this context the problem of the stabilization of the euro in order for it to be competitive with the dollar.
\end{abstract}

Key words: Monetary union, economic crisis, economic growth, the euro, competitiveness, integrations, management.

JEL classification: E52, F45, G01, A14

\section{ЕВРОПСКА МОНЕТАРНА УНИЈА КАО ФАКТОР СТАБИЛИЗАЦИЈЕ У ОКОЛНОСТИМА ЕКОНОМСКЕ КРИЗЕ}

\section{Апстракт}

Ауйори истиражују ироблеме Евройске монеитарне уније у околносииима свейске економске кризе. Посебно су елаборирали борбу за финансијску

\footnotetext{
${ }^{1}$ srecko.milacic@pr.ac.rs, ORCID ID 0000-0002-2802-4608

2 zoki@medianis.net, ORCID ID 0000-0002-2769-6867

${ }^{3}$ aleksandar.kostic@pr.ac.rs ORCID ID 0000-0002-6315-0765
} 
сииабилносии Евройске монеитарне уније. Ауйори ирроблемайизују инииеракиију Евройске иенитралне банке и националних иенитралних банака, указујући на манкавостии координације фискалне и монетиарне йолитике. Они су

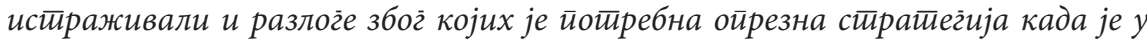
иитиануйријемновихчланицау Евройскумонетиарнунију иуйомсмислууслове економске и иравне конвергениије. Проблемаиизују уиравльюье економском кризом и увођене нових инстиитуиија чији би задайак био стиабилизоване сииана у монешиарној обласии. Исираживали су и ироблеме йомоћи земљама иойуй Грчке. Посебно су обрайили йажну на иррансиаренитносии ириликом дономена йојединих одлука о йомоћи. Они су ирредложили решень за излазак из зачараног круга йойребом редизајнираға евройске монейарне уније. Као и стиабилизације евра како би био конкуренйан долару.

Клучне речи: Монейарна унија, економска криза, иривредни расй, евро,

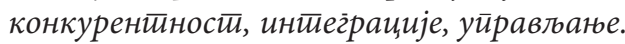

\section{Introduction}

The Monetary Union is the result of the integration and cohesion processes in the European Union that eventually became more and more profound. The economies of the European countries gradually became more interrelated, thus creating the need for a common currency. Prior to using the common currency it was necessary to adjust a common policy. The founding of the European Central Bank and the common market expressed the willingness of member states not to consider only their own interests when it comes to the EU, but to have a much broader perspective of the problems of integration. Taking into account the previous experiences, it is understandable that the EMU (the European Monetary Union) was accepted with scepticism. However, the time has shown that the euro is a stable currency despite the crisis and its consequences that are still present. The claims that the European Monetary Union was the cause or that, at least, it contributed to the crisis in the Eurozone are controversial, if nothing else. Simply, no one can deny the fact that the euro has contributed to the growth of the output, transaction costs were much lower and the allocation of capital in the Eurozone was more effective. It is obvious that the problems which have arisen in relation to the euro are rather the result of fiscal policies. Also, euro sceptics got an impulse from the fact that the monetarists deemed the euro as a currency that cannot be stable in the long run. In particular, the issue was the potential increase in aggregate output or the occurrence of losses due to the abandoning of the national currency. This problem was addressed by Mundell, who thought that it was very important for the budget to be centralized and for the transfer of funds to take place under strictly defined rules. This, in fact, means that the transfer of funds is not preceded by exhausting political bargaining (Mundell, 1961, pp. 657-665). The theory of optimum currency areas points out the common economic characteristics of the countries as a prerequisite for their successful functioning. Under the Maastricht Treaty there were certain criteria of nominal convergence that were to be met when introducing the common currency. It is clear that the EU countries are at different levels of economic development which is a problem when it comes to joining the European 
Monetary Union (EMU). Namely, the last two enlargements of the European Union in 2004 and 2007 showed that only four of the twelve countries that joined the EU met the criteria regarding the introduction of a common currency, the euro. With the advent of the global economic crisis in 2008, there were serious problems with interest rates and the exchange rate. The European Central Bank had to examine the overall situation in the European Monetary Union in order to come up with a solution by a quality fiscal policy, especially when it comes to budget deficits. The point is that in such cases measures have to be taken to reduce expenditure. Such measures imply the reduction of salaries, pensions and other costs, which leads to a rapid decline in living standards of the population. In such circumstances economic science usually recommends structural reforms that should lead to a reduction of fiscal imbalances.

The aim of our work is to examine and analyse the mechanisms and ways of functioning of the EMU and regarding that, nominal and real convergence. Also, we want to point out the controversy over understanding the problems of effectiveness of the European Monetary Union. Namely, the dilemma lies in the question whether the very participation in the Monetary Union is a prerequisite for an easier exit from the crisis or, on the contrary, an independent monetary policy can more effectively respond to the economic crisis.

\section{The Creation of the European Monetary Union}

The European Monetary System was showing deficiencies, so the reform was inevitable. Thus, there was a need for creating a new system and it was the EMU. Prior to forming the new common currency, the Deutschmark was the most important currency. The Central Banks of the countries which operated mostly with Germany used to implement the same measures as the German Central Bank. These countries generally disapproved of switching to the euro. However, at that time, France as the creator of the EU insisted on a consistent monetary system and even greater unity of the member states. Of course, apart from the interests of the Union, France was considering its own interests and was not willing to allow the supremacy of Germany. On the other hand, greater liberalization of capital flows was necessary for the common market program and its implementation. The point was that a constant currency conversion was not in accordance with the common market. That is why Jacques Delors openly stated in 1990 that „we need a common currency before 2000“ (Delors, 1990, p. 1). Delors had a decisive influence on the formation of the EMU, demanding from the Council to urgently bridge the barriers on the road to the EMU. Even before this process there had been some economists who claimed that the "common market with a common policy may be a sustainable in the long run only within a harmonious framework of macro and monetary policy“ (Kaiser et al., 1983, p. 13). Delors was encouraged by the attitude of HansDietrich Genscher, the German minister of foreign affairs, who felt it was important to establish a common central bank and currency. As the president of the Commission, Delors had a great influence on the monetary and in general the economic policy. He cooperated with the leaders of the central banks of the member states and struggled for the idea of a common Central Bank to be accepted by them. However, the influence of Delors was not as significant as the influence of the leaders of member countries, such as 
François Mitterrand and Helmut Kohl. As it was eventually becoming clear that the EMU will become a reality, Mitterrand was becoming more and more an advocate of deeper European integration that marked his political career. „Indeed, Mitterrand made the leitmotif of his presidency of out of building Europe“ (Dinan, 2010, p. 457). Mitterrand was trying to win Kohl and slowly made their relation closer and closer. "During a visit to Aachen in October 1987... Mitterrand spoke greatly about the common destiny of France and Germany. As the engine of European integrations, France and Germany have to be the leaders in a number of areas, including monetary policy (Dinan, 2010, p. 222). The German Central Bank was against this project because it was convinced that the idea represented the interests of the French and German politicians, not the economy. Cohl waited for the German Central Bank to accept the idea. Generally, Germany was not pleased with the EMU because the Bundesbank was losing its monopoly. The German Central Bank doubted whether the EMU will be capable enough to ensure stable prices.

Successful functioning of the Monetary Union, given the differences between the countries, was threatened. These differences were reflected in the levels of unemployment, inflation, then the labour market institutions, legal system, GDP growth, fiscal balance (De Grove, 2004). However, the member states were required to meet the legal and economic criteria of convergence. Article 140 of the Treaty on the Functioning of the EU defined these criteria. Upon the request of a member state, the Commission and the ECB were obliged to report to the European Council on its progress when it comes to meeting its commitments regarding the Monetary Union. The report contained information on the compliance of the Statute, the national laws and the statutes of the central banks with Article 130 and 131 of the Statute of the ESCB and the ECB. The questions of price stability and the inflation rate were also important. Of course, they should not deviate significantly from the countries with the most stable budgets (Article 126). All this implies the exchange rate stability. The criteria that are under consideration were included in the Protocol on the convergence criteria (Lučić, 2011, p. 62).

\section{The European Monetary Union: Struggle for Financial Stability}

In the course of history, there were no sovereign states that voluntarily renounced their own national currencies in favour of a common currency. The introduction of the euro as a kind of experiment has remained an interesting topic for professional discussions. The point is that its introduction has political, economic and monetary dimension and significantly affects the quality of the interactions that are taking place within the framework of the European integration (Issing, 2015, p. 361-372).

With the formation of the European Central Bank, the European Monetary Union was actually building a new system, thus institutionalizing the integration processes. In this way it acquired a respectable reputation. However, the biggest problem was the harmonization of monetary policy by the ECB with the economies of the member states. By making monetary decisions, the European Central Bank reinforces the confidence of the member states in its credibility, despite the fact that certain problems may arise due to inexperience. The task of the EMU, among other things, is to stabilize the European monetary system through maintaining stable prices. „By doing so, the Euro system contributes to minimizing disruption in the allocation of resources, supports the 
economic growth on the level of the productive potentials of the economies" (Hitiris, 2003, p. 142). The European Monetary Union facilitated the functioning of the common market with its measures, so the "Common Market meant the Customs Union of the states and the functioning of the four fundamental freedoms: (1) The free movement of goods (2) the free movement of services/business environment, (3) the free movement of people and (4) the free movement of capital“ (Mintas Hodak, 2010, p. 30).

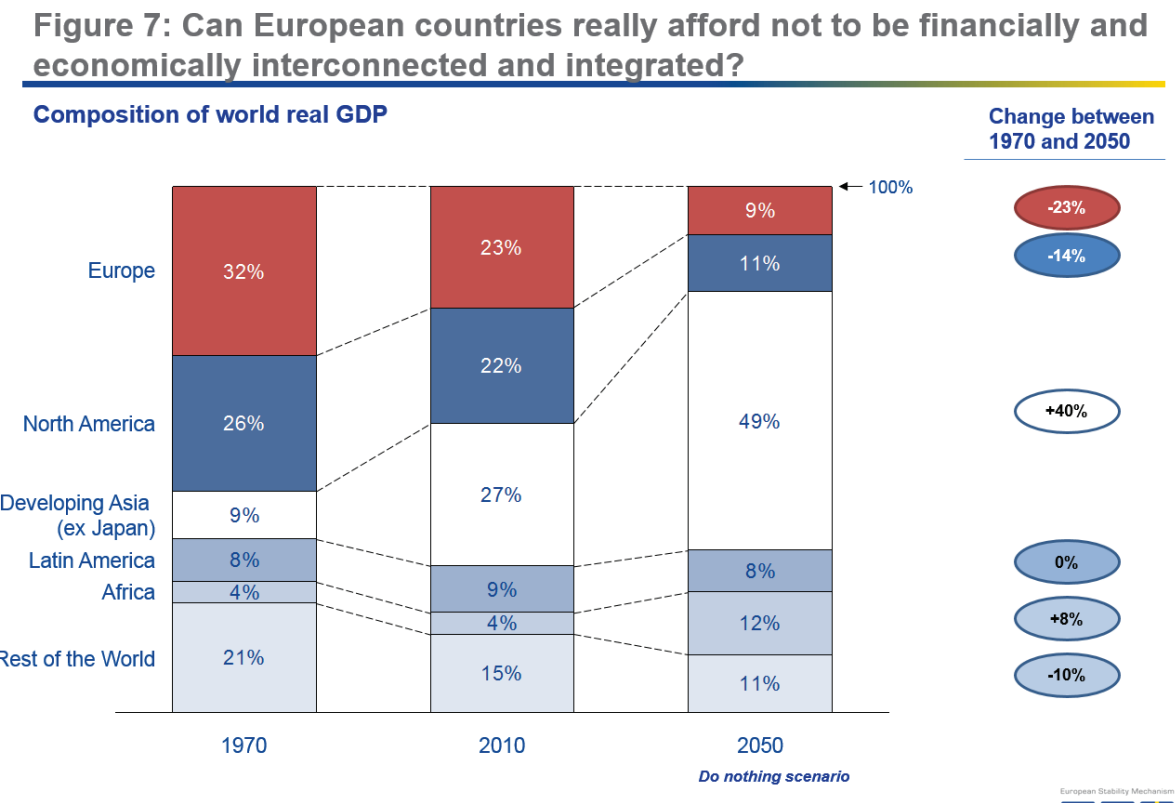

Source: IMF World Economic Outlook; Citi Investment Research and Analysis

Retrieved from Janse, K. (2016). How the financial crisis made Europe stronger? https://www.weforum.org/agenda/2016/03/how-the-financial-crisis-made-europestronger/ (20.03.2019).

When the EMU was created the question was whether the management of this institution would be conducted in the right way and how it would function. The European monetary system had to respond to various challenges. „The first and most obvious was the release of the euro as a real currency in circulation in January 2002. The challenge was mainly about logistics and information. It was related to the printing of the euro banknotes, delivering of the new currency, withdrawal of the old currency... In the meantime, the Commission launched a huge campaign called 'Euro 2002' to inform the public and the governments conducted similar campaigns at the national level“" (Dinan, 2009, p. 479). The rejection of the national currencies and the transition to the euro proceeded according to the plan. Nothing surprising or bad happened, in fact, everything functioned smoothly. The „devices that worked on coins did not stuck, ATMs did not melt, there was no epidemic of allergic reactions to the new alloy coins spreading the Earth and no inflation bonfire was lit in the winter sky above the Eurozone“ (Beber 2002, p.77). Beber's sarcastic sense of humour only captures the atmosphere of expectation that prevailed before the introduction of the 
currency. The new currency was quickly accepted and the old banknotes forgotten. The member states had a deadline of six months to finish all transactions in the old currency. The spirit of togetherness was felt much stronger by using the common currency. This change meant even deeper European integration. The euro became a symbol of stability. However, there were also some problems. As always, human greed could not be avoided in this case, too. Namely, companies increased prices by rounding the value of the goods. However, this was insignificant compared to the benefits that the common currency brought: the cross-border competition was stricter, customers did not lose money when converting the currency, which had a positive impact on the free market. The euro is now the currency appreciated worldwide due to the economic strength of the member states. The common currency has proven to be extraordinarily useful. It affects in its way the initiation of a common competition policy which applies to banking matters. What is missing is the more explicit financial management. In many areas, the Europeans have not even started to harmonize national policies: many "contracts“ are banned in some countries while permitted in others; certain practices and speculations are encouraged in some places, while are underestimated in others (Atali, 2010, p. 131). The European Monetary Union has an important cohesive force. However, in times of crisis the Union should find a „European lender that is not the European Central Bank, nor are the national governments, nor EIB, but a new entity whose mission is to provide guarantees to European financial institutions which are in difficulty, if they are viable, and to be able to participate in their capital and to provide them with the debt in question" (Atali, 2010, p.132). However, the problems of the European Monetary Union arise from the error „that the EU made when it deindustrialized the countries that had surrounded the Soviet Union by a shock therapy and then integrated them overnight. This proved to be the economic Achilles heel of Europe during the financial crisis" (Rejnert, 2010, p. 184). That is way structural reforms are very important today. They should include the consolidation of debt to the various institutional mechanisms. Within the European Monetary Union, the European Central Bank could issue bonds in euros for which the guarantor would be the whole Eurozone. The yield would be lent to various Eurozone countries or the European Union countries. It is believed that such a system is productive because it allows greater borrowing (Bibow, 2015). We should bear in mind that this solution also has drawbacks because every debt has its risks that have to be taken into account when making sensitive decisions.

\section{The Institutions Affecting the EMU}

Situating a common monetary policy of the member states is not possible without the European Central Bank. Its role is advisory, regulatory and executive. However, it is important to note that the European Central Bank does not only control the monetary policy of the EMU member countries, but also of countries that do not use the euro. Among other things, it participates in the process of drafting legislation, consults, it gives recommendations and opinions. Because of the nature and the importance of the work that it does, its impact on the Council is evident. The European Central Bank, given the strength of the European Union has a significant impact on the work of the WTO, G-20 and many other organizations. Therefore, resolving monetary issues on the global scale is not possible without the participation of the EU. 
As for the interaction of the national central banks and the European Central Bank, when a state is in need of increasing the money supply, the European Central Bank has the authority to give approval. In the field of cooperation with the International Monetary Institutions, the Central Bank plays the leading role. It provides specific advice and recommendations relating the monetary policy. This cooperation does not exclude countries that do not use the euro.

Apart from the European Central Bank, the monetary policy is also affected by the European Parliament. It adopts measures essential to the functioning of the euro and, if necessary, changes the articles of the Statute of the European Central Bank. As for the Council, when adopting new regulations the Parliament has an advisory role. This does not mean that the Parliament has no right to adopt new measures together with the Council and the ECB - just the opposite, in fact.

The Council is an institution that takes care of the integration of monetary policy. With the participation of other institutions, it also provides solutions important for the overall operation of the monetary union. This means that it controls the operations of financial institutions. It particularly supervises credit institutions. In the area of fiscal discipline the Council conceives certain measures and regulations that are adopted.

The European Commission is also responsible for the implementation of the monetary policy. The Commission makes proposals and recommendations to the executive branches of the EMU, regarding the common commercial policy and markets. This is particularly true for the balance of payments. During the financial crisis in some of the EMU countries it has the power in relation to the recommendations that should be implemented in practice. It gives them to the Council and the Council further approves financial assistance and the like. Such help can be used by the countries that do not use the euro as currency. We have already stated the fact that the Commission may have an advisory role to the European Parliament and the Council with regard to amendments of the Articles of the Statute of the ESCB and the ECB. Of course, this means that it had previously received relevant regular reports on the economic situation, capital flows and the like. Every two years the European Commission submits reports to the Council on the progress of each member country. The European Commission requests the opinion and regular reports from the European Financial Committee in regard of the economic and financial situation in the EU, which also includes financial relations with third countries. This is primarily true for the movement of capital. Usually, after consulting the European Financial Committee, the Commission makes recommendations to the Council to extend the aid to the member states but also to deny it if it does not lead to the desired result. The European Commission makes proposals regarding possible amendments to Articles of the Statute and the Council adopts them. The Commission's role is important if there is an imbalance of payments and proposes protective measures that the Council should approve in accordance with Article 143 TFEU (Georgieva, 2011, pp. 76-77). The European Monetary Union should work on expanding the existing European institutions. Thus, the European Investment Bank in addition to focusing on credit projects for infrastructure, environment and climate change, should have a wider role, which would be reflected in the additional recapitalization (Stiglic, 2016, p. 275). All the mentioned institutions can affect the functioning of the EMU and the potential problems occur due to their imperfections. 
Progress made under various headings according to the Index of European institutional integration (EURII):

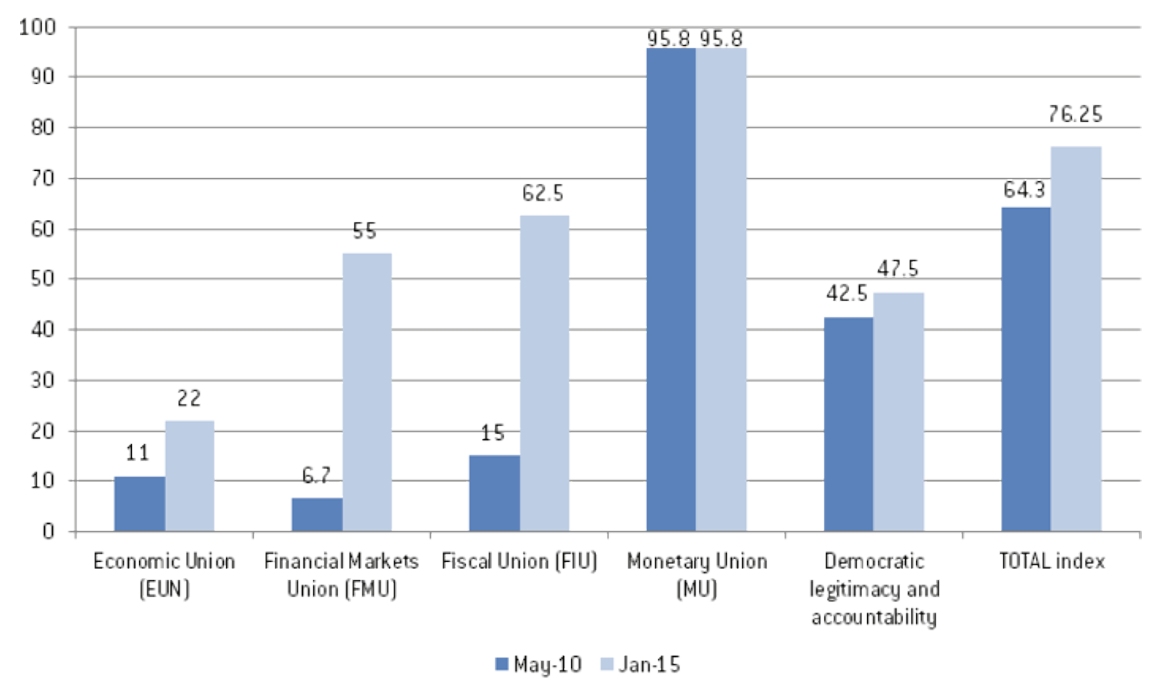

Retrieved from Terzi, A. (2015). How should we coordinate economic policy in the Eurozone. https://www.weforum.org/agenda/2015/10/how-should-we-coordinateeconomic-policy-in-the-eurozone/

\section{The Condition of the Real and Nominal Convergence}

In order to understand better the problems that arise on the road towards monetary unification (especially when it comes to new member state) we should point out the criteria that are they obliged to fulfil in order to achieve nominal and real convergence. In addition to what is defined in the theory of optimal currency areas (mobility of production factors, the level of trade openness, the quality and level of integration of financial markets, the flexibility of prices and wages, the alignment of business cycles and the like) (Mongelli, 2002, p. 5), the degree of convergence achieved by the member states of the European Union is also very important. It is about the nominal and real convergence of the member states. On the other hand, we must bear in mind that the „EU structure was being built long and patiently. The basic approach of its foundation was the functional approach. The member states transferred only a small part of their jurisdiction to the Union, which kept their integrity and sustainability of the Union, often at the expense of the efficiency of operation. The introduction of the EMU was a tectonic shift in the process. National independence in the conduct of monetary policy was submitted to the ECB. On the other hand, appropriate mechanisms of coordination with other economic policies were not established. In a word, there were no institutions in the EMU to offer successful response to asymmetric shocks" (Grbić, Todić, 2014, p. 28). This is precisely the problem of the European Union because a number of countries did not comply with the convergence criteria, especially when it comes to the budget deficit and public debt growth. This reflected the shortcomings of an institutional nature 
and, of course, political. The point is that if the economy was to be asked, the states would have to adhere to certain rules of supranational institutions. However, this involves the transfer of jurisdiction when it comes to fiscal sovereignty, which is usually politically disapproved. The importance of coordination between fiscal and monetary policy can be seen from the difficulties of central national banks of a number of the EU member states to maintain the targeted level of inflation. Of course, the difficulties arise from the fact that the monetary authority is not able to control all the instruments essential to inflation and exchange rates. Certain problems come from the fact that when we talk about the European Union, we talk about a heterogeneous set of fiscal policies. What does this mean? The leaders of the developed countries such as the UK, Germany, France and Denmark reasonably pose a question why their citizens should pay and save the member states that are in trouble? The obvious example is Brexit or the UK leaving the European Union. Although its reasons for this decision are complex, sometimes controversial, this is one of the most frequently mentioned examples. Part of Catalonians' dissatisfaction derives from similar reasons, only on the inner level (Catalonia is the most developed part of Spain).We should not forget that even the developed countries have their budget deficits, with the difference that they are capable of financing them. However, this does not mean that if the current practice extends for some time, they won't become illiquid.

All new EU member states are obliged to introduce the euro as a common currency, but that does not mean that they will soon become members of the European Monetary Union. For that, they have to meet certain conditions (criteria) to achieve nominal and, accordingly, the real convergence. Namely, after the establishment of the ECB, the convergence reports are within its jurisdiction and are always available on its website. The ECB does not support the practice of introducing the euro without the procedure, although, for example, Montenegro is not a member of the EU and has accepted the euro as its currency. It is one of the paradoxes that was initiated by politics and unfortunately, Atlantic geo-strategy which only suggests that the European Union is not independent. For the successful functioning of the Monetary Union, we need to know that it is very important that there are no major differences between the countries in terms of inflation and unemployment. Also, there should be no disbalance when it comes to labour markets. There should be no differences in the legal system, either in the rate of GDP growth, nor in the fiscal system. The founding Agreement suggests criteria of economy's convergence that the EU member states have to fulfil to be eligible members of the EMU. For their reception, it is important for them to fulfil both the conditions of legal and real convergence. Practice has shown that the optimum period of joining the EMU is after ten years of EU membership. When it comes to the criteria for real convergence, the analysis of the fulfilment of the conditions and the procedure itself are determined by Article No. 140 of the Treaty on the Functioning of the EU. Namely, at the request of a Member State that did not meet the benchmarks, the Commission and the ECB report to the Council every two years on its progress. The report analyses the degree of sustainable convergence, which includes: price stability, then inflation rate, which should not differ significantly from the level of inflation in the three most stable Member States. Fulfilling the conditions of economic convergence also implies sustainable budgetary finances. The deficit should not be higher than that established by Article 126. Fluctuations in the exchange rate must be normal. This implies that for at least two years there has been no devaluation of the national currency against the euro. The achieved convergence must 
be stable, as can be seen from the level of long-term interest rates. These criteria are still monitored and elaborated, that is, the achieved results related to market integration, balance of payments, movement of labour costs and price index are examined. Thereafter, there is a debate in the European Parliament and the European Council where, on the proposal of the Commission, a decision is made whether the deviation member has fulfilled the conditions of economic convergence. The agreement on the European Union which was concluded in Maastricht in 1992 stated all the conditions that had to be met in order for a member of the European Union to enter the European Monetary Union. The first and the basic condition is that such countries must have stable prices. In other words, the inflation rate should not exceed $1.5 \%$ compared to the three countries with the most stable prices. The requirement is that this should be for a year prior to the admission in the EMU. The second condition is that the budget deficit does not exceed 3\% of GDP. It is obvious that special attention is paid to fiscal discipline. In this context, the public debt must not exceed $60 \%$ of GDP. The third and no less important condition is related to the stability of the exchange rate. There should be at least a two-year participation in the exchange rate mechanism with respect to fluctuations of $+/-15 \%$ against the euro and finally, long-term interest rates must not exceed $2 \%$ of interest rate in the three EU countries that had the most stable prices in previous year (European Communities Council, 1992). As for the ECB's convergence report, it analyses the level of sustainable economic convergence as well as the compatibility of national legislation with the Agreement. If it is found that it is OK, the NCBs may become an integral part of the Eurosystem. Article 130 of the Agreement regulates the adjustment of national legislation which allows the independence of the Central Bank. When assessing legal convergence, not only the formal side is crucial, but also the provisions that comply with the spirit of the Agreement Statute. When it comes to compatibility, the ECB also makes conclusions as to whether the legislation complies with the secondary legislation of the Union. Namely, it should bear in mind that it also has a primacy in relation to national legislation. Article 124 of the Treaty on the Functioning of the EU prohibits any measure that allows or encourages privileged access to financial institutions. The ban on monetary financing is aimed at achieving price stability. The exception is Article 2 of the Special Regulation (Regulation EC No 3603/93). This article provides that the NCB can finance liabilities to the IMF and approve the so-called night loans to the public sector with a 24-hour return period. Based on the ECB's Convergence Report, it can be concluded that there are frequent deviations from the reference values for the criteria of economic convergence and the non-compliance of national legislation with the EU Treaty on the Functioning. This incompatibility of national legislation also applies to the Statute of the ESCB and the ECB. However, when it came to adopting the Agreement on the stability, this change was explicitly opposed by the Czech Republic and the United Kingdom. After Brexit, it is clear why the United Kingdom had done so. On the other hand, the Czech Republic has skilfully managed to avoid fulfilling the Maastricht criteria for years, regardless of the fact that it was obliged to join the European Monetary Union. Something similar is done by Sweden because its citizens have been opposing this form of economic integration for many years. The European Union and the Eurozone face controversy as well as the crisis. The reasons are many, but the most important is the poor management of the crisis, which has led to distrust of the citizens in the deeper integration of the member states. The effect of meeting the conditions of nominal and real convergence did not ensure 
the expected EMU stability, hence the amended Stability and Growth Pact was amended and adopted. The aim was to help Union resist the crisis in the most successful way. Subsequently, a Stability Agreement was adopted, which represents an upgrade of the aforementioned Pact. This very Agreement caused a lot of controversy as it anticipated the abolition of the independent and supervisory function of the parliaments. Despite its adoption, this Agreement only distanced the Member States from each. All this shows that the controversy will only multiply after the Brexit, that is when the United Kingdom leaves the European Union.

\section{The Economic Crisis and the EMU}

The emergence of the economic crisis gripped the world and affected functioning of most institutions. In this context, the crisis has shown that the EMU requires a sort of redesign, if it is to succeed. We have to bear in mind that there has always been a "quiet disagreement" between some individual member states and the Union. The problems emerged due to the rotten compromises. Namely, the member states have transferred parts of their jurisdiction that did not encroach on their integrity but also the credibility of the Union or, as some authors noted "the secrecy of the Union" (Grbić, Todić, 2014, p. 28). It is this shadowy side that is slowly crumbling institutions of the Union, in particular those concerning the financial sector. That's why a modern financial regulation is needed. What does this mean? In the recent years, with the growth of the economic crisis the opinion prevailed with some researchers that deregulation is to blame for such situation. It was thought that the free and often chaotic market economy caused the problems rather than regulated them. However, one should not forget that practically there was no financial deregulation before the crisis occurred, at least when it comes to the European Union. Legislation that would, for example, separate commercial from investment banking was lifted. But the laws that were passed afterwards only increased the scope of regulation and made the functioning of the financial institutions even more bureaucratic. "As bureaucracy does, the regulation also grows exponentially. One regulation leads to another" (Tasić, 2016, p. 141). Thus, with the advent of the crisis, representatives of the European Union realized that something had to be done with the redesigning of the EMU, so in 2010 the decision was made to establish the European financial stability facility (EFSF). The initial capital of the EFSF amounted 750 billion euros. The amount of the fund was decided by the European Council in 2011. The IMF participated in the financing of the fund with 250 billion euros under its own terms. On one hand, this meant reducing the public debt and achieving budget savings, and on the other, doing the same with social benefits, benefits for health care, pensions and wages and then increasing indirect taxes especially those on value added tax (Kuenzel, 2011, pp . 7-14). The motives for the IMF to participate in the establishment of the Fund show that it was more about eliminating the symptoms rather than the causes. Namely „macroeconomic measures -aimed directly at the budget, deficits and debt... have led to economic decline, recession and depression that afflict Europe“ (Stiglic, 2016, p. 210). However, such a policy and participation in the Fund has, as we have already said, the shadowy side because "the creditor states, such as Germany, do not want their taxpayers to learn about the cost that may be imposed to them; they would like their citizens to believe that they would be paid 
off, although this is practically impossible“ (Stiglic, 2016, p. 210). This type of the EMU redesign has not proved to be effective since the crisis has not passed yet. The reductions in current account deficits of vulnerable countries like Greece, Portugal, Spain, etc. are more a result of falling demand than the result of the EFSF establishment. The IMF did not take long to come to a conclusion about the importance of introducing tax measures. In fact, if they are poorly designed the results will be reflected in a decline of revenues, which means that a solution to the crisis cannot be expected in this manner. The request of the Fund for some countries to reduce their deficit is a complex and often unmanageable job when it comes to countries like Greece. No common fund within the redesigned European Monetary Union could reduce the unsustainable and large deficit that had been „cherished" for years. A simple recipe of the Fund creation did not mean that the states would be financed without certain conditions, such as austerity programs, reducing costs and increasing taxes. Everything in the economy is a cause-consequence event. The fact that savings usually slow the economy and decrease revenues was underestimated, while at the same time certain expenditures of social nature rise, such as those for unemployment insurance and various types of assistance to those in need. We also tend to oversee the fact that such problems cause affected people to oppose the integrations (the growth EU scepticism). Obviously, this good intention has not delivered the expected results. The fund itself has its economic function but it cannot save endangered countries from the crisis. This type of redesigning the European Monetary Fund, despite the huge funds, could not solve the accumulated problems. On the other hand, the market as we know it today produces socially unacceptable levels of inequality. In this way, instead of healing an economy, it undermines it. It is obvious that even within the frames of monetary policy it is important to try to redesign the European monetary institutions to compensate for the gained advantage of the intergenerational type (Stiglic, 2015, p. 425-448). In doing so, one should take into account the fact that the European Monetary Union implies the existence of a common central bank. But the problem is that forming of the Monetary Union with countries that have high inflation reduces welfare of the countries with low inflation. Hence, institutionalism means consideration of all relevant issues that can be resolved if those in charge of the constitutional design study them well and adopt new laws that will be appreciated by all.

Prior to the outbreak of the crisis the euro was publicly promoted as a significant and stable currency and it was even speculated that in the foreseeable future it could „replace the US dollar as the preferred reserve currency, with all the political and economic impact that would bring. It will take time for these levels of optimism and confidence to return and the reorganization of the euro will imply surrendering greater national control to the European Central Bank and to a group of financial agencies. However, the benefits of the common currency will always exceed its costs, and the revived and changed euro will have an added advantage in the fact that it will be managed by those who have gone through a deep learning curve and have developed a better understanding of its limitations and possibilities" (McCormick, 2015, p. 170). It is obvious that premature conclusions and euphoria are not recommended in the economy. 


\section{Conclusion}

The successful functioning of the Monetary Union requires a continuous work on reducing the differences between the member states (in terms of unemployment, inflation, the labour market institutions, legal system, GDP growth and fiscal balance). All this cannot be achieved without the quality work of the institutions that affect the EMU. The European Monetary Union adjusted monetary policy by formation of the European central bank and thereby strengthened the trust of the member states. The European Monetary Union affected the quality of functioning of the common market with its measures. The Euro as a common currency contributed to the tightening of cross-border competition, the customers did not lose on currency exchange, and the free market functioned better. It is necessary to improve financial management to solve better the accumulated problems. This includes the harmonization of national policies. Certain practices in speculations that have proved productive over the management mechanisms should be continuously improved. Providing mobility in the European financial institutions is also one of the priorities. It is believed that in the European Monetary Union, the European Central Bank can issue bonds in euros for which the guarantor would be the whole Eurozone.

The condition of the nominal and real convergence is important because the given criteria secured reaching higher level of real convergence. This requires ensured stable prices, the level of inflation and the amount of the budget deficit that cannot be exceeded, fiscal discipline and exchange rate stability.

The European Union and the Eurozone are facing a deep crisis, so there was a need for better management, which led to the adoption of the amended Stability and Growth Pact. The abolition of the independent and parliamentary control has caused certain controversy. Brexit was followed by other complex issues.

With the advent of the economic crisis there was a need to redesign the EMU. This is how the European financial stability facility (EFSF) was formed. The IMF also took part in its formation. The largest creditors like Germany were not transparent to their citizens for the fear that their taxpayers would not agree with that. Thus, the controversy about how to manage the crisis magnified. However, the problem has remained because the market continues to produce socially unacceptable levels of inequality. Those responsible for constitutional design are yet to enact new laws that will be appreciated by everyone and that would guarantee better results.

\section{References}

Atali, Ž. (2010). Kriza a posle? [The crisis. What next?]. Beograd: Hedone.

Beber, M. (2002). One Careful Driver from New: Earning the European Central Bank's No-Claims Bonus. Journal of Common Market Studies Annual Rewiew, 40 (1), 75-80.

Bibow, J. (2015). Making the Euro Viable (Working Paper No. 842). NY: Levy Economics Institute. Retrieved from: https://www.boeckler.de/pdf/v_2015_10_23_bibow. pdf 
De Grove, P. (2004). Ekonomija monetarne unije [The economy of the Monetary Union]. Novi Sad: Izdavačka knjižarnica Zorana Stojanovića.

Delors, J. (29.10.1990). Interview in Wall Street Journal.

Dinan, D. (2009). Sve bliža unija [Ever closer Union]. Beograd: Službeni glasnik.

Durkalić, D., Furtula, S., \& Borisavljević, K. [2019]. Rangiranje perfomansi turističkog tržišta u zemljama EMU - rezultati PROMETHEE - GAIA pristupa. Menadžment u hotelijerstvu i turizmu, 7(2), 67-76.

European Communities - Council (1992), Treaty on Europena Union, Luxembourg: Office for Official Publications of the European Communitie. Retrieved from: https://europa.eu/europeanunion/sites/europaeu/files/docs/body/treaty_on_ european_union_en.pdf

Georgieva, E. (2011). The role of EU institutions in implementing its monetary policy. Eastern Journal of European Studies, 2, (1), 67-79.

Grbić, V. i Todić, D. (2014). Konkurentnost privrede i kriza Evropske unije [The competitiveness of the economy and the crisis of the European Union], Bankarstvo, br. 2/2014 Retrieved from: http://www.ubs-asb.com/Portals/0/ Casopis/2014/2/UBS-Bankarstvo-2-2014-Grbic-Todic.pdf

Hitiris, T. (2003). European Union Economics. Harlow: Pearson Education.

Issing, O. (2015). Completing the Unfinished House: Towards a Genuine Economic and Monetary Union? International Finance, 18, (3), 361-372. DOI: 10.1111/ infi.12076.

Janse, K. (2016). How the financial crisis made Europe stronger? Available at https:// www.weforum.org/agenda/2016/03/how-the-financial-crisis-made-europestronger/ (20.03.2019).

Kaiser, K., De Mondbrial, T., Wallace, W. \& Wellenstein, E. (1983). The European Community: Progres or Decline? London: RIIA.

Kuenzel, R. (2011). The EU's comprehensive policy response from the crisis. In: European Commision (Ed.), Quarterly report on the euro area, 10 (1), 7-15.

Lučić, Lj. (2011). Evropska monetarna unija i Srbija [The European Monetary Union and Serbia]. Bankarstvo, br. 9-10/2011 Retrieved from: http://www.ubs-asb.com/ Portals/0/Casopis/2011/9_10/UBS-Bankarstvo-09-10-2011-Lucic.pdf

McCormic, J. (2015). Zašto je Evropa važna - argumenti za Evropsku uniju [Why is Europe important - arguments in favour of the EU]. Zagreb: Mate.

Mintas Hodak, Lj. (2010). Europska unija [the European Union]. Zagreb: MATE d.o.o.

Mongelli, F. P. (2002). New Views on the Optimum Currency Area Theory: What is EMU Telling us? (Working paper 138), Frankfurt: European Central Bank. Retrieved from: https://www.ecb.europa.eu/pub/pdf/scpwps/ecbwp138.pdf?7f9fcb71c9a79 e446251a79273c9ba60 Accessed on: 15. March 2017.

Mundell, R., (1961). A theory of Optimal Currensy Areas. American Economic Review, $51(4), 657-665$.

Rejnert, E. (2010). Spontani haos - ekonomija u doba vukova [Spontaneous chaos the economy in times of wolves]. Beograd: Čigoja štampa. 
Stiglic, E. Dž.(2016). Evro: kako zajednička valuta ugožava budućnost Evrope [The euro: How a Common Currency Threatens the Future of Europe]. Novi Sad: Akademska knjiga.

Stiglic, E. J. (2015). The origins of Inequality and Policies to Contain it. National Tax Journal, 68, (2), 425-448.

Stevović-Buha, J. [2015]. Kako razumeti Evropsku uniju. Anali Ekonomskog fakulteta u Subotici, (33), 49-60.

Tasić, S. (2016). Šta je kapitalizam?: i zašto nam je potreban [What is capitalism?: And why we need it]. Smederevo: Heliks.

Terzi, A. (2015). How should we coordinate economic policy in the Eurozone. Available at https://www.weforum.org/agenda/2015/10/how-should-we-coordinate-economicpolicy-in-the-eurozone/ (19.05.2019). 
